\title{
Dual Specificity Protein Phosphatase 3
}

National Cancer Institute

\section{Source}

National Cancer Institute. Dual Specificity Protein Phosphatase 3. NCI Thesaurus. Code C25856.

Dual specificity protein phosphatase $3(185 \mathrm{aa}, \sim 20 \mathrm{kDa}$ ) is encoded by the human DUSP3 gene. This protein plays a role in protein dephosphorylation. 